\title{
Pengaruh Budaya Organisasi Dan Komitmen Organisasi Terhadap Kinerja Karyawan
}

\author{
Muhammad Ras Muis \\ Program Studi Manajemen Fakultas Ekonomi dan Bisnis \\ Universitas Muhammadiyah Sumatera Utara \\ Email:mrasmuis1979@gmail.co.id

\section{J Jufrizen} \\ Program Studi Manajemen Fakultas Ekonomi dan Bisnis \\ Universitas Muhammadiyah Sumatera Utara \\ email : jufrizen@umsu.ac.id

\section{Muhammad Fahmi} \\ Program Studi Manajemen Fakultas Ekonomi dan Bisnis \\ Universitas Muhammadiyah Sumatera Utara \\ email :mfahmi4343@yahoo.co.id
}

\footnotetext{
Abstract budaya organisasi dan komitmen organisasi terhadap kinerja pegawai. Populasi adalah jumlah keseluruhan dari objek penelitian. Adapun populasi dalam penelitian ini adalah seluruh pegawai yang ada pada PT Pegadaian (Persero) Kanwil I - Medan, yang berjumlah 60 orang. Karena sedikitnya jumlah pegawai pada perusahaan, maka penelitian ini tidak menggunakan penarikan sampel. Sehingga sampel dalam penelitian ini adalah seluruh jumlah pegawai pada PT Pegadaian (Persero) Kanwil I - Medan, yang berjumlah 60 orang. Teknik pengumpulan data dalam penelitian ini adalah daftar pertanyaan (questioner), studi dokumentasi dan wawancara (interview). Sedangkan teknik analisis data yang digunakan adalah regresi linier berganda, uji asumsi klasik, uji t, dan uji F dan koefisien determinan. Hasil penelitian menunjukkan bahwa secara parsial ada pengaruh positif dan signifikan budaya organisasi terhadap kinerja, ada pengaruh positif dan signifikan komitmen organisasi terhadap kinerja, dan secara simultan ada pengaruh positif dan signifikan budaya organisasi dan komitmen organisasi terhadap kinerja karyawan.

\section{Keyword Budaya Organisasi, Komitmen Organisasi dan Kinerja}

This study aims to determine the effect of partial and simultaneous organizational culture and organizational commitment to the performance of employees. The population is the sum total of the object of research. The

Abstract population in this study is all employees who exist in PT Pegadaian (Persero) Kanwil I - Medan, which amounts to 60 people. Due to the small number of employees in the company, this study did not use sampling. So the sample in this study is the total number of employees at PT Pegadaian (Persero) Kanwil I Medan, which amounts to 60 people. Data collection techniques in this study is a list of questions (questioner), study documentation and interviews (interview). While the data analysis technique used is multiple linear regression, classical
}

Penelitian ini bertujuan untuk mengetahui pengaruh secara parsial dan simultan 
assumption test, $t$-test, and $F$ test and determinant coefficient. The result of this research shows that there are positive and significant influence of organizational culture on performance, and there are positive influence and significant organizational culture and organizational commitment to employee

Keyword performance.

Organizational Culture, Organizational Commitment and Performance

\section{PENDAHULUAN}

Kinerja merupakan suatu hasil kerja yang dicapai seseorang dalam melaksanakan tugas-tugas yang dibebankan kepadanya yang didasarkan atas kecakapan, pengalaman dan kesungguhan serta waktu. Kinerja ini adalah gabungan dari tiga faktor penting yaitu kemampuan dan minat seseorang pekerja, kemampuan dan penerimaan atas penjelasan delegasi tugas dan peran serta tingkat motivasi seorang pekerja. Semakin tinggi ketiga faktor di atas, maka semakin besarlah kinerja pegawai bersangkutan (Hasibuan, 2011 : 94).

Masalah-masalah empiris yang terlihat pada PT Pegadaian (Persero) Kanwil I Medan yang berpengaruh dengan kinerja pegawai diantaranya adalah kurangnya kemampuan pegawai dalam melakukan pekerjaan dengan baik, hal ini dapat terlihat dari masih ada pegawai yang salah melakukan nilai taksiran barang gadai sehingga dapat merugikan perusahaan. Selain itu terlihat beberapa pegawai yang telat dalam melaporkan pekerjaan yang harus segera dilaporkan seperti rekap barang gadaian yang dilakukan setiap harinya tetapi pegawai tersebut belum mampu menyelesaikannya sesuai dengan waktu yang telah ditentukan. Permasalahan yang menyangkut kemampuan pegawai harus segera diselesaikan dengan baik. Keterbatasan pegawai yang handal, yang menguasai operasional perusahaan merupakan masalah yang mendasar dalam perbaikan kinerja perusahaan. Usaha peningkatan kualitas sumber daya manusia akan juga mencakup peningkatan kemampuan manajerial dan operasional perusahaan.

PT Pegadaian (Persero) Kanwil I - Medan sebagai perusahaan tidak lepas dari lingkaran persaingan bisnis. Keunggulan di bidang sumberdaya manusia atau dalam pelayanan disebut sumberdaya merupakan salah satu faktor untuk memenangkan kompetisi di dunia bisnis saat ini. Semakin cepatnya kemajuan ilmu pengetahuan harus diimbangi dengan sumberdaya manusia yang kaffah (sempurna). Hal ini tentunya perlu dicermati terutama dalam menghadapi era persaingan global dimana pesaing usaha bukan hanya datang dari industri sejenis, akan tetapi juga dari industri lainnya yang memiliki kemampuan yang sama. Komitmen organisasi merupakan komponen dari perilaku. Komitmen organisasi adalah suatu keadaan dimana seorang karyawan memihak pada suatu organisasi dan tujuan-tujuannya, serta berniat memelihara keanggotaannya itu. Keterlibatan seseorang yang tinggi dalam suatu pekerjaan berarti memihak pada pekerjaan tertentu seorang individu, sementara komitmen organisasi yang tinggi berarti memihak organisasi yang merekrut individu tersebut. (Robbins, $2013: 69$ ).

Komitmen pegawai pada organisasi merupakan dimensi perilaku yang dapat digunakan untuk mengukur dan mengevaluasi kekuatan pegawai dalam bertahan dan melaksanakan tugas dan kewajibannya pada organisasi. Komitmen di pandang sebagai suatu orientasi nilai terhadap organisasi yang menunjukkan individu sangat memikirkan dan mengutamakan pekerjaan dan organisasinya. Individu akan berusaha memberikan segala usaha yang dimilikinya dalam rangka membantu organisasi mencapai tujuannya. (Mathins dan Jackson, 2011 : 122), demikian juga hal nya apa yang diungkapkan oleh Nasution (2017), bahwa para karyawan yang memiliki komitmen yang kuat akan tetap tinggal bersama organisasi. 
Fenomena komitmen organisasi pada PT Pegadaian (Persero) Kanwil I - Medan yaitu masih kurangnya keinginan beberapa pegawai untuk memajukan perusahaan, dimana pegawai yang seharus melayani nasabah dengan baik, tetapi tidak lakukan dengan maksimal, hal ini terlihat dari bagaimana cara pegawai tersebut menjalankan pekerjaannya.

Selain komitmen organisasi, salah satu faktor yang mempengaruhi kinerja adalah budaya organisasi. Seperti yang dikemukakan Wibowo (2010: 363) yaitu: suatu organisasi biasanya dibentuk untuk mencapai suatu tujuan melalui kinerja segenap sumber daya manusia yang ada dalam organisasi. Namun, kinerja sumber daya manusia sangat ditentukan oleh kondisi lingkungan internal maupun eksternal organisasi, termasuk budaya organisasi. Karenanya, kemampuan menciptakan suatu organisasi dengan budaya yang mampu mendorong kinerja adalah suatu kebutuhan. Masalah-masalah yang berkaitan dengan budaya organisasi perusahaan diantaranya kurangnya teladan dari pimpinan dalam hal datang dan pulang kerja tepat pada waktunya sehingga hal tersebut membudaya atau menjadi tradisi dikalangan pegawai sehingga banyak pegawai yang datang dan pulang juga tidak tepat waktunya. Untuk itu perusahaan harus dapat menciptakan budaya organisasi/perusahaan yang positif sehingga berpengaruh terhadap kinerja pegawai, hal ini diperkuat dengan pendapat Jufrizen dan Radiman (2010) yang mengatakan bahwa Budaya organisasi berkaitan dengan bagaimana karyawan mempersepsikan karakteristik dari budaya suatu organisasi, bukannya dengan apa mereka menyukai budaya itu atau tidak. Artinya, budaya itu merupakan suatu istilah deskriptif. Budaya organisasi menyatakan suatu persepsi bersama yang dianut oleh anggota-anggota organisasi itu.

\section{LANDASAN TEORI}

\section{Kinerja}

Dalam melaksanakan kerjanya, pegawai menghasilkan sesuatu yang disebut dengan kinerja. Kinerja merupakan hasil kerja seseorang pegawai selama periode tertentu dibandingkan dengan berbagai kemungkinan misalnya standard, target/sasaran atau kriteria yang telah ditentukan terlebih dahulu dan disepakati bersama. Kinerja adalah hasil kerja yang dapat dicapai oleh seseorang atau sekelompok orang dalam suatu organisasi, sesuai dengan wewenang dan tanggung jawab masing-masing, dalam rangka upaya mencapai tujuan organisasi bersangkutan secara legal, tidak melanggar hukum dan sesuai dengan norma dan etika. Mangkunegara (2010 : 67) mengatakan: "Kinerja adalah hasil kerja secara kualitas dan kuantitas yang dicapai oleh seseorang pegawai dalam melaksanakan tugasnya sesuai dengan tanggung jawab yang diberikan kepadanya.

Pernyataan di atas dengan jelas memperlihatkan bahwa istilah kinerja merupakan hasil kerja yang dinyatakan dalam kualitas dan kuantitas oleh seorang pegawai. Hasibuan (2011 : 94) mengatakan: "Kinerja adalah suatu hasil kerja yang dicapai seseorang dalam melaksanakan tugas-tugas yang dibebankan kepadanya yang didasarkan atas kecakapan, pengalaman, dan kesungguhan serta waktu.

Sedangkan Hariandja (2009 : 195) menyatakan: "Kinerja merupakan hasil kerja yang dihasilkan oleh pegawai atau perilaku nyata yang ditampilkan sesuai dengan peranannya dalam organisasi. Dari di atas hanya sebagai hasil kerja dari seorang pegawai. Kinerja kayawan merupakan suatu hal yang sangat penting dalam suatu organisasi untuk meningkatkannya. Salah satu adalah melalui penilaian kinerja atau manajemen kinerja. Untuk mencapai kinerja yang baik, unsur yang paling dominan adalah sumber daya manusia, walaupun perencanaan telah tersusun dengan baik dan rapi tetapi apabila orang atau personil yang melaksanakan tidak berkualitas dan tidak memiliki semangat kerja yang tinggi, maka perencanaan yang telah disusun tersebut akan sia-sia. 
Kinerja yang dicapai pegawai merupakan suatu hal yang sangat penting dalam menjamin kelangsungan hidup organisasi. Dalam mencapai kinerja yang tinggi beberapa faktor yang mempengaruhi menjadi pemicu apakah kinerja pegawai tinggi atau rendah. Mangkunegara (2010 : 67) manyatakan faktor-faktor yang mempengaruhi kinerja pegawai adalah:

1) Faktor Kemampuan

Secara psikologis, kemampuan (ability) pegawai terdiri dari kemampuan potensi (IQ) dan kemampuan reality (Knowledge + skill). Artinya, pegawai yang memiliki IQ di atas rata-rata (IQ 110-120) dengan pendidikan yang memadai untuk jabatannya dan terampil dalam mengerjakan pekerjaan sehari-hari, maka ia akan lebih mudah mencapai prestasi yang diharapkan. Oleh sebab itu pegawai perlu ditempatkan pada pekerjaan yang sesuai dengan keahliannya.

2) Faktor Motivasi

Motivasi terbentuk dari sikap (attitude) seorang pegawai dalam menghadapi situasi kerja. Motivasi merupakan kondisi mengerakkan diri pegawai yang terarah untuk mencapai tujuan organisasi (tujuan kerja).

William Stern dalam Mangkunegara (2010 : 16) menyatakan bahwa faktorfaktor penentu kinerja individu adalah faktor individu dan faktor lingkungan kerja organisasi.

1) Faktor Individu

Secara psikologis, individu yang normal yang memiliki integritas yang tinggi antara fungsi psikis (rohani) dan fisiknya (jasmaniah). Dengan adanya integritas yang tinggi antara fungsi psikis dan fisik, maka inidividu tersebut memiliki konsentrasi diri yang baik. Konsentrasi yang baik ini merupakan modal utama individu manusia untuk mampu mengelola dan mendayagunakan potensi dirinya secara optimal dalam melaksanakan kegiatan atau aktivitas kerja sehari-hari dalam mencapai tujuan organisasi

2) Faktor Lingkungan Organisasi

Faktor lingkungan kerja organisasi sangat menunjang bagi individu dalam mencapai kinerja. Faktor lingkungan organisasi yang dimaksud antara lain uraian jabatan yang jelas, autoritas yang memadai, target kerja yang menantang, pola komunikasi kerja efektif, hubungan kerja harmonis, iklim kerja respek dan dinamis, peluang berkarir dan fasilitas kerja yang relatif memadai.

Mathis dan Jakson (2011 : 78) berpendapat bahwa kinerja pada dasarnya adalah apa yang dilakukan atau tidak dilakukan pegawai. Kinerja pegawai adalah yang mempengaruhi seberapa banyak mereka membei kontribusi kepada organisasi yang antara lain termasuk: 1) Kuantitas output, 2) Kualitas output, 3) Jangka waktu output, 4) Kehadiran di tempat kerja, dan 5) Sikap kooperatif. Sedangkan menurut Mangkunegara (2010 : 75) unsur-unsur yang dinilai dari kinerja adalah : 1) Kualitas kerja, 2) Kuantitas

kerja, 3) Keandalan dan 4) Sikap. Kualitas kerja terdiri dari ketepatan, ketelitian, keterampilan, kebersihan. Kuantitas kerja terdiri dari output dan penyelesaian kerja dengan ekstra. Keandalan terdiri dari mengikuti instruksi, inisiatif, kehati-hatian, kerajinan. Sedangkan sikap terdiri dari sikap terhadap perusahaan, pegawai lain dan pekerjaan serta kerjasama.

\section{Budaya Organisasi}

Budaya organisasi berkaitan dengan bagaimana pegawai mempersepsikan karakteristik dari budaya suatu organisasi, bukannya dengan apa mereka menyukai budaya itu atau tidak. Artinya, budaya itu merupakan suatu istilah deskriptif. Budaya organisasi merupakan suatu persepsi bersama yang dianut oleh semua anggota organisasi. 
Luthans dalam Asri Laksmi (2011 : 6) menyatakan: ” Budaya organisasi merupakan norma-norma dan nilai-nilai yang mengarahkan perilaku anggota organiassi. Setiap anggota akan berperilaku sesuai dengan budaya yang berlaku agar diterima oleh lingkungannya." Selanjutnya Feter F. Druicker dalam Pabundu Tika (2008 : 4) menyatakan: Budaya organisasi adalah pokok penyelesaian masalah-masalah eksternal dan internal yang pelaksanaannya dilakukan secara konsisten oleh suatu kelompok yang kemudian mewariskan kepada anggota-anggota baru sebagai cara yang tepat untuk memahami, memikirkan dan merasakan terhadap masalah-masalah terkait serperti di atas.

Menurut Sutrisno (2010:72) : Budaya organisasi adalah sebagai perangkat sistem nilai-nilai (values), atau norma-norma (beliefs), asumsi-asumsi (asssumptions), atau norma-norma yang telah lama berlaku, disepakati dan diikuti oleh para anggota suatu organisasi sebagai pedoman perilaku dan pemecahan masalah-masalah organisasinya.

Budaya organisasi memiliki peran yang sangat strategis untuk mendorong dan meningkatkan efektivitas kinerja organisasi, khususnya kinerja pegawai baik dalam jangka pendek maupun jangka panjang. Peran budaya organisasi adalah sebagai alat untuk menentukan arah organisasi, mengarahkan apa yang boleh dan tidak boleh dilakukan, bagaimana mengalokasikan sumber daya organisasional dan juga sebagai alat untuk menghadapi masalah dan peluang dari lingkungan organisasi.

Menurut Kreitner dan Kinicki (2013 : 83) budaya organisasi mempunyai empat

(4) fungsi yaitu:

1) Memberikan identitas kepada pegawainya

2) Memudahkan komitmen kolektif

3) Mempromosikan stabilitas sistem sosial

4) Membentuk perilaku dengan membantu manajer merasakan keberadaannya.

Tiap karakteristik ini berlangsung pada suatu kontinum dari rendah ke tinggi. Maka dengan menilai organisasi itu berdasarkan tujuh karakteristik ini, akan diperoleh gambaran majemuk dari budaya organisasi suatu organisasi.

Menurut Andreas Lako (2006 : 31) fungsi budaya organisasi untuk:

1) Memberikan sense of identity kepada anggota organisasi untuk memahami visi, misi dan menjadi bagian integral dari organisasi.

2) Menghasilkan dan meningkatkan komitmen terhadap misi organisasi.

3) Memberikan arah dan memperkuat standard perilaku untuk mengendalikan pelaku organisasi agar melaksanakan tugas dan tanggungjawab mereka secara efektif dan efisien untuk mencapai tujuan dan sasaran organisasi yang telah disepakati bersama.

4) Membantu dalam mendesain kembali sistem pengendalian manajemen.

5) Membantu manajemen dalam penyusunan skema sistem kompensasi manajemen untuk eksekutif dan pegawai

6) Sebagai sumber daya kompetitif perusahaan apabila dikelola dengan baik.

Para peneliti telah berusaha mengidentifikasi dan mengukur beberapa tipe budaya organisasi dalam rangka mempelajari hubungan antara tipe efektivitas dan organisasi. Pencarian ini didorong oleh kemungkinan bahwa budaya tertentu lebih efektif dibandingkan dengan yang lain. Menurut Kreitner dan Kinicki (2013 : 86) bahwa secara umum terdapat tiga (3) jenis budaya organisasi yaitu:

1) Budaya konstruktif

Budaya konstruktif adalah budaya dimana para pegawai didorong untuk berinteraksi dengan orang lain dan mengerjakan tugas dan proyeknya dengan cara yang akan membantu mereka dalam memuaskan kebutuhannya untuk tumbuh dan berkembang. Tipe budaya ini mendukung keyakinan normatif yang berhubungan dengan pencapaian tujuan aktualisasi diri, penghargaan yang manusiawi dan persatuan. 
2) Budaya pasif-defensif

Budaya pasif - defensif bercirikan keyakinan yang memungkinkan bahwa pegawai berinteraksi dengan pegawai lain dengan cara yang tidak mengancam keamanan kerja sendiri. Budaya ini mendorong keyakinan normatif yang berhubungan dengan persetujuan, konvensional, ketergantungan, dan penghidupan.

3) Budaya agresif defensif

Budaya agresif - defensif mendorong pegawainya untuk mengerjakan tugasnya dengan kerja keras untuk melindungi keamanan kerja dan status mereka. Tipe budaya ini lebih bercirikan keyakinan normatif yang mencerminkan oposisi, kekuasaan, kompetitif dan perfeksionis.

Meskipun sebuah organisasi dapat menampilkan satu tipe budaya organisasi secara menonjol, ia tetap dapat menunjukkan keyakinan normative dan karakteristik yang lain. Riset menunjukkan bahwa organisasi dapat memiliki sub budaya fungsional, sub budaya hierarkis berdasarkan posisi seseorang dalam organisasi, sub budaya geografis, sub budaya pekerjaan berdasar pada gelar atau posisi seseorang, sub budaya sosial yang diambil dari aktivitas sosial seperti budaya liga bowling atau golf dan budaya berlawanan. (Kreitner dan Kinicki, 2013 : 87 - 89). Budaya kerja yang ada di perusahaan sebagai suatu "strategi" organisasi dibentuk oleh beberapa variabel. Setiap variabel memiliki karakteristik yang unik. Noe dan Mondy dalam (Andreas Lako, 2006 : 53) mengidentifikasi dua variabel lingkungan yang membentuk dan mempengaruhi efektivitas budaya kerja dalam suatu organisasi.

Pertama, fator-faktor yang berasal dari variabel lingkungan internal perusahaan. Faktor-faktor tersebut meliputi:

1) Misi, visi, rules, dan nilai-nilai yang ditanamkan oleh para pendahulu (founders).

2) Nilai-nilai yang ditanamkan secara konkret oleh para pemimpin

3) Komitmen, moral, etika serta suasana kekerabatan dari kelompok-kelompok kerja.

4) Gaya kepemimpinan manajer lini

5) Karakteristik organisasional seperti bentuk dan aktivitas utama, otonomi, dan kompleksitas perusahaan, sistem penghargaan, sistem komunikasi, konflik/kerjasama, serta toleransi terhadap resiko dalam proses administrasi perusahaan.

Kedua, faktor-faktor yang berasal dari lingkungan global, seperti kecenderungan perubahan ekonomi, tuntutan hukum dan politik, tuntutan social, perkembangan teknologi manufaktur, transformasi teknologi informasi dan perubahan ekologi.

Robbins (2013 : 247) menyatakan riset paling baru mengemukakan tujuh karakteristik primer yang bersama-sama menangkap hakikat dari suatu budaya suatu organisasi yaitu:

1) Inovasi dan pengambilan resiko

Sejauhmana pegawai diorong untuk inovatif dan mengambil resiko 
2) Perhatian

Sejauhmana pegawai diharapkan memperlihatkan presisi, analisis dan perhatian kepada rincian.

3) Orientasi hasil

Sejauhmana manajemen memusatkan perhatian pada hasil bukannya pada teknik dan proses yang digunakan untuk mencapai hasil itu.

4) Orientasi orang

Sejauhmana keputusan manajemen memperhitungkan efek hasil-hasil pada orangorang di dalam organisasi itu.

5) Orientasi tim

Sejauhmana kegiatan kerja diorganisasikan sekitar tim-tim, bukanya individuindividu.

6) Keagresifan

Sejauhmana orang-orang itu agresif dan kompetitif dan bukannya santai-santai.

7) Kemantapan

Sejauhmana kegiatan organisasi menekankan dipertahankannya status quo daripada pertumbuhan.

Wirawan (2010 : 16-17) menyebutkan dimensi budaya kerja internal meliputi asumsi-asumsi:

1) Locus control

Misalnya apakah akryawan dapat mengontrol output tindakan mereka atau tidak.

2) Sifat penurut (malleability)

Misalnya apakah sifat pegawai dapat dirubah atau tidak.

3) Orientasi ke masa depan (futuristic orientation)

Misalnya apakah pegawai dalam merencanakan tindakannya berorientasi pada masa depan atau tidak.

4) Proaktivitas/reaktivitas (proactivity/reactivity)

Mengenai apakah pegawai mengambil inisiatif personal atau sekedar bereaksi terhadap permintaan ekstern ketika mencoba objektif pekerjaannya atau tidak

5) Pencari tanggung jawab (responsibility seeking)

Misalnya apakah pegawai menerima dan mencari tanggung jawab dalam pekerjaannya atau tidak atau tidak.

6) Partisipasi (Participation)

Misalnya apakah pegawai lebih menyukai delegasi pada semua level dan senang dikonsultasikan mengenai sesuatu yang berhubungan dengan mereka.

7) Kewajiban kepada orang lain (obligation toward others)

Misalnya apakah pegawai merasa berkewajiban untuk memenuhi kewajiban mereka kepada orang lain di tempat kerja

\section{Komitmen Organisasi}

Komitmen organisasi secara umum merupakan suatu ketentuan yang disetujui bersama dari semua personil dalam suatu organisasi mengenai pedoman, pelaksanaan serta tujuan yang ingin dicapai bersama dimasa yang akan datang. Defenisi dari komitmen organisasi sangat banyak dan masing-msing pendapat berbeda sesuai dengan ahli yang menyatakan pendapat tersebut. Salah satu definisi komitmen organisasi dijelaskan oleh Russ dan McNeily dalam Wening (2005 : 5) yang menyatakan bahwa: "Komitmen organisasi merupakan identifikasi seseorang dan loyalitas pada organisasi.

Porter dalam Mutiara (2009, hal 135) menyatakan : "komitmen organisasi adalah kuatnya pengenalan dan keterlibatan seseorang dalam suatu organisasi tertentu.

Sedangkan Becker dalam Mutiara (2009 : 125) juga menyatakan bahwa: "komitmen 
organisasi adalah kecenderungan untuk terikat dalam garis kegiatan yang konsisten karena menganggap adanya biaya pelaksanaan kegiatan yang lain (berhenti bekerja)."

Menurut Mathis dalam Sopiah (2008 : 155): "Komitmen organisasi adalah derajat yang mana pegawai percaya dan menerima tujuan-tujuan organisasi dan akan tetap tinggal atau tidak akan meninggalkan organisasi.

Secara singkat pada intinya beberapa defenisi komitmen organisasi dari beberapa ahli diatas mempunyai penekanan yang hampir sama yaitu : proses pada individu (pegawai) dalam mengidentifikasikan dirinya dengan nilai-nilai, aturan-aturan dan tujuan organisasi. Dalam dunia kerja, komitmen seseorang dalam organisasi perusahaan seringkali menjadi isu yang penting. Begitu pentingnya hal tersebut, sampai-sampai beberapa organisasi berani memasukan unsur komitmen sebagai salah satu syarat untuk memegang suatu jabatan/posisi yang ditawarkan dalam iklan -iklan lowongan pekerjaan. Sayangnya meskipun masih belum memahami arti komitmen secara sungguh-sungguh. Padahal pemahaman tersebut sangatlah penting agar tercipta kondisi kerja yang sangat kondusif sehingga perusahaan dapat berjalan efektif dan efisien.

Kanter (1986) dalam Sopiah (2008 : 158), mengemukakan :

1. Komitmen berkesinambungan (continuance commitment), yaitu komitmen yang berhubungan dengan dedikasi anggota dalam melangsungkan kehidupan organisasi dan menghasilkan orang yang mau berkorban dan berinvestasi pada organisasi;

2. Komitmen terpadu (cohesion commitment), yaitu komitmen anggota terhadap organisasi sebagai akibat adanya hubungan sosial dengan anggota lain di dalam organisasi. Ini terjadi karena karyawan percaya bahwa norma-norma yang dianut organisasi merupakan norma-norma yang bermanfaat;

3. Komitmen terkontrol (control commitment), yaitu komitmen anggota pada norma anggota organisasi yang memberikan perilaku yang diinginkannya. Norma yang dimiliki organisasi mampu memberikan sumbangan terhadap perilaku yang diinginkannya.

Menurut Meyer, Allen, dan Smith (1998) dalam Sopiah, (2008 : 157) mengemukakan tiga komponen komitmen organisasional, yaitu:

1. Affective commitment, terjadi apabila karyawan ingin menjadi bagian dari organisasi karena adanya ikatan emosional;

2. Continuance commitment, muncul apabila karyawan tetap bertahan pada suatu organisasi karena membutuhkan gaji dan keuntungan lain, atau karena tidak menemukan pekerjaan lain;

3. Normative commitment, timbul dari nilai-nilai dalam diri karyawan. Karyawan bertahan menjadi anggota organisasi karena adanya kesadaran bahwa komitmen terhadap organisasi merupakan hal yang seharusnya dilakukan.

Komitmen organisasi yang telah diterapkan dan menjadi pedoman bagi pegawai untuk terus meningkatkan loyalitas kerjanya sangat dipengaruhi berbagai faktor dalam pencapainnya. Stun dalam Sopiah (2008 : 164) mengemukakan ada 5 faktor yang berpengaruh terhadap komitmen organisasi yaitu: "(1) budaya keterbukaan, (2) kepuasan kerja, (3) kesempatan personal untuk berkembang, (4) arah organisasi dan (5) penghargaan kerja yang sesuai dengan kebutuhan. Selain itu komitmen organisasi juga memberikan berbagai faktor yang mempengaruhinya, hal ini ditegaskan oleh steers dalam Sopiah (2008 : 156) yang menyatakan bahwa faktor yang mempengaruhi komitmen organisasi adalah sebagai berikut :

1) Kepercayaan

Pegawai yang memiliki komitmen organisasi tentunya akan merasa bangga dapat bergabung dengan perusahaannya. Dalam kerangka komitmen, kepercayaan pegawai 
pada organisasi menyebabkan antara lain pegawai merasa organisasi mampu memenuhi kebutuhan dan menyediakan sarana yang diperlukan.

2) Kemauan

Kemauan pegawai untuk bekerja lebih giat dan dengan sekuat tenaga demi mencapai tujuan organisasi mencerminkan tingginya tingkat komitmen pegawai. Dengan adanya kemauan dari para pegawai paling tidak dapat digunakan untuk memprediksi tingkah laku pegawai, dalam hal ini tanggung jawabnya pada perusahaan.

3) Kesetiaan

Secara umum kesetiaan menunjuk kepada tekad dan kesanggupan mentaati, melaksanakan dan mengamalkan sesuatu yang disertai dengan penuh kesadaran dan tanggung jawab. Pegawai yang mempunyai kesetiaan yang tinggi pada perusahaan tercermin dari sikap dan tingkah lakunya dalam melaksanakan tugas serta tekad dan kesanggupan mereka terhadap apa yang sedang disepakati bersama.

Komitmen organisasi merupakan rasa kepercayaan kepada perusahaan yang besar kecilnya dipengaruhi beberapa indikator pendukung. Menurut Steers dalam Sopiah (2008 : 156), komitmen organisasi dapat dilihat dari 3 faktor:

1) Kepercayaan dan penerimaan yang kuat atas tujuan dan nilai-nilai organisasi.

2) Kemauan untuk mengusahakan tercapainya kepentingan organisasi

3) Keinginan yang kuat untuk mempertahankan keanggotaan organisasi.

Konsep komitmen pada organisasi yang tercantum dalam penelitian ini diadaptasi dari pendapat Lincoln dalam Sopiah (2008 : 156) yaitu meliputi :

1) Kemauan

Kemauan pegawai untuk bekerja lebih giat dan dengan sekuat tenaga demi mencapai tujuan organisasi mencerminkan tingginya tingkat komitmen pegawai. Dengan adanya kemauan dari para pegawai paling tidak dapat digunakan untuk memprediksi tingkah laku pegawai, dalam hal ini adalah tanggung jawabnya pada perusahaan. Di samping itu pegawai akan mempunyai perasaan ikut memiliki perusahaan sehingga mereka akan bertanggung jawab, baik untuk kemajuan dirinya sendiri maupun perusahaan. Mereka akan menyelesaikan pekerjaan dengan sebaik-baiknya, tepat pada waktunya dan berani menanggung resiko dari keputusan yang diambilnya.

2) Kesetiaan

Secara umum kesetiaan menunjuk kepada tekad dan kesanggupan mentaati, melaksanakan dan mengamalkan sesuatu yang disertai dengan penuh kesadaran dan tanggung jawab. Pegawai yang mempunyai kesetiaan yang tinggi pada perusahaan tercermin dari sikap dan tingkah lakunya dalam melaksanakan tugas serta tekad dan kesanggupan mereka terhadap apa yang sedang disepakati bersama.

3) Kebanggaan

Pegawai yang memiliki komitmen pada organisasi tentunya akan merasa bangga dapat bergabung dengan perusahaan. Dalam kerangka komitmen, kebanggan pegawai pada organisasi disebabkan antara lain pegawai merasa organisasi mampu memenuhi kebutuhan dan menyediakan sarana yang diperlukan. Di samping itu pegawai menyadari bahwa perusahaan mempunyai citra yang baik di masyarakat. Dan lebih jauh pegawai yakin bahwa perusahaan akan terus berkembang seiring dengan kemajuan informasi dan teknologi.

\section{Kerangka Konseptual}

\section{Pengaruh Budaya Organisasi terhadap Kinerja}

Budaya organisasi adalah kepribadian perusahaan yang tumbuh oleh sistem nilai yang menimbulkan norma yang mengenai perilaku yang tercermin dalam persepsi, sikap dan perilaku orang-orang yang ada di dalam organisasi ataupun 
perusahaan tersebut dengan demikian budaya mempengaruhi sebagian besar aspek kehidupan organisasi ataupun perusahaan. Menurut Sutrisno (2010:6) menyatakan bahwa: Budaya organisasi yang benar-benar dikelola sebagai alat manajemen akan berpengaruh dan menjadi pendorong bagi pegawai untuk berperilaku positif, dedikatif dan produktif. Nilai-nilai budaya itu tidak tampak, tetapai merupakan kekuatan yang mendorong perilaku untuk menghasilkan efektivitas kinerja. Kreitner dan Kunicki dalam Sopiah (2008 : 183) mengemukakan bahwa: Kinerja atau prestasi kerja individu sangat dipengaruhi oleh budaya nasional yang menjadi inspirasi lahirnya budaya organisasi. Jika perusahaan memiliki budaya organisasi yang baik maka kepuasan kerja akan menjadi tinggi dan berdampak pada peningkatan kinerja. Sebaliknya, jika budaya organisasi tidak sehat maka hal itu akan memicu penurunan kinerja individu anggota organisasi yang pada gilirannya akan berpengaruh terhadap kinerja organsiasi.

Menurut Wilda dan Azra (2007) dalam jurnalnya menyimpulkan bahwa: "budaya organisasi berpengaruh positif dan signifikan terhadap kinerja karyawan Politeknik Negeri Padang”. Mulyadi dkk (2012) dalam jurnalnya menyimpulkan bahwa: "Ada pengaruh positif dan signifikan antara budaya organisasi terhadap kinerja pegawai pada Dinas Bina Marga dan Pengairan Kabupaten Karawang".

\section{Pengaruh Komitmen Organisasi terhadap Kinerja}

Dalam dunia kerja, komitmen seseorang terhadap profesinya maupun organsiasi tempat bekerja seringkali menjadi isu yangs angat penting. Bahkan beberapa organsiasi berani memasukkan unsur komitmen sebagai salah satu persyaratan untuk memegang jabatan atau posisi yang ditawarkan dalam iklan lowongan-lowongan kerja, hal ini menunjukkan pentingnya komitmen di dalam dunia kerja. Komitmen kerja di perusahaan tidak terlepas dari bentuk hubungan antara pegawai dengan pekerjaan atau profesi di tempat pegawai tersebut bekerja demi tercapainya tujuan bisnis yang diinginkan oleh perusahaan tersebut (Rozikin, 2012: 12).

Komitmen organisasi merupakan keinginan kuat untuk tetap sebagai anggota organisasi tertentu, dengan kata lain, ini merupakan sikap mereklefsikan kinerja pegawai pada organisasi dan proses berkelanjutan dimana anggota organisasi mengekspresikan perhatiannya terhadap organisasi dan keberhasilannya serta kemanjuan yang berkelanjutan untuk tetap berada tetap dalam organisasi.

Fred Luthans (2006 : 250) menunjukan bahwa: "ada hubungan yang positif antara komitmen organisasi dan hasil yang diinginkan seperti kinerja yang tinggi". Melizawati (2015) dalam penelitiannya menyimpulkan bahwa: "komitmen organisasi mempunyai pengaruh penting terhadap kinerja karyawan pada PT. Indotirta Abadi. semakin tinggi komitmen karyawan, maka kinerja karyawan akan semakin meningkat".

\section{METODOLOGI PENELITIAN}

Pendekatan penelitian ini adalah penelitian asosiatif. Penelitian ini menggunakan metode pendekatan asosiatif, yaitu suatu metode penelitian yang berusaha menggambarkan suatu fenomena atau gejala yang terjadi dalam keadaan nyata pada waktu penelitian dilakukan, dengan menggunakan data yang berbentuk data laporan keuangan sebagai sampel dari populasi yang diambil, untuk kemudian dianalisis untuk mengetahui apakah variabel terkait yang diteliti mempunyai hubungan yang signifikan atau tidak. 
Populasi adalah jumlah keseluruhan dari objek penelitian. Adapun populasi dalam penelitian ini adalah seluruh pegawai yang ada pada PT Pegadaian (Persero) Kanwil I Medan, yang berjumlah 60 orang. Karena sedikitnya jumlah pegawai pada perusahaan, maka penelitian ini tidak menggunakan penarikan sampel. Sehingga sampel dalam penelitian ini adalah seluruh jumlah pegawai pada PT Pegadaian (Persero) Kanwil I Medan, yang berjumlah 60 orang.

Teknik pengumpulan data yang digunakan adalah:

1. Daftar pertanyaan (Quesioner), yakni data dengan membuat daftar pertanyaan dalam bentuk angket yang ditujukan kepada pegawai PT Pegadaian (Persero) Kanwil I Medan dengan menggunakan skala likert dengan bentuk checklist, dimana setiap pertanyaan mempunyai 5 opsi

2. Studi dokumentasi yaitu mempelajari dokumen-dokumen yang ada dalam perusahaan tentang sejarah singkat perusahaan dan struktur organisasi serta jumlah pegawai yang ada di perusahaan.

3. Wawancara (Interview), yaitu mengadakan tanya jawab dengan pihak-pihak yang berkompeten memberikan data yang penulis perlukan.

Teknik analisis yang digunakan dalam penelitian ini adalah analisis Regresi Linier Berganda dengan persamaan:

$\mathrm{Y}=\mathrm{a}+\mathrm{b}_{1} \mathrm{X}_{1}+\mathrm{b}_{2} \mathrm{X}_{2}+\epsilon$

(Sugiyono, 2012: 221)

Dimana:

$\mathrm{Y}=$ Kinerja

$\mathrm{a}=$ Harga $\mathrm{Y}$ bila $\mathrm{X}_{1}$, dan $\mathrm{X}_{2}=0$ (harga konstan)

$\mathrm{b}=$ Angka arah koefisien regresi

$\mathrm{X}_{1}=$ Budaya Organisasi

$\mathrm{X}_{2}=$ Komitmen Organisasi

$\epsilon=$ error of term

\section{HASIL PENELITIAN}

Uji Asumsi Klasik

Dengan regresi linear berganda dikenal dengan beberapa asumsi klasik regresi berganda atau dikenal juga BLUE (Best Linear Unbias Estimation). Pengujian asumsi klasik secara sederhana bertujuan untuk mengidentifikasi apakah regresi merupakan model yang baik atau tidak. Ada beberapa pengujian asumsi klasik tersebut, yakni :

a. Normalitas

Pengujian normalitas data dilakukan untuk melihat apakah dalam model regresi, variabel dependen dan independenya memiliki distribusi normal atau tidak. Jika data menyebar disekitar garis diagonal dan mengikuti arah garis diagonal maka model regresi memenuhi asumsi normalitas. 
Dependent Variable: Kinerja (Y)

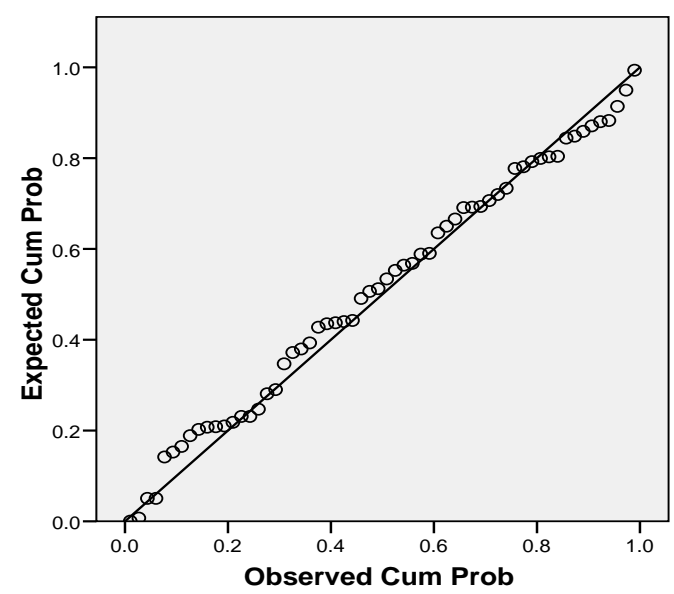

Gambar 1. Normalitas

Gambar diatas mengidentifikasikan bahwa model regresi telah memenuhi asumsi yang telah dikemukakan sebelumnya, sehinnga data dalam model regresi penelitian ini cenderung normal.

b. Multikolinearitas.

Multikolinearitas digunakan untuk menguji apakah pada model regresi ditemukan adanya korelasi yang kuat antar variabel independen. Cara yang digunakan untuk menilainya adalah dengan melihat nilai faktor inflasi varian (Variance Inflasi Factor/VIF ), yang tidak melebihi 4 atau 5 .

\section{Tabel 1. Multikolinearitas.}

\begin{tabular}{|c|c|c|c|c|c|c|c|c|}
\hline \multicolumn{9}{|c|}{ Coefficients ${ }^{\mathrm{a}}$} \\
\hline \multirow[b]{2}{*}{ Model } & & \multicolumn{2}{|c|}{$\begin{array}{l}\text { Unstandardized } \\
\text { Coeff icients }\end{array}$} & \multirow{2}{*}{$\begin{array}{c}\text { Standardized } \\
\text { Coeff icients }\end{array}$} & \multirow[b]{2}{*}{$t$} & \multirow[b]{2}{*}{ Sig. } & \multicolumn{2}{|c|}{ Collinearity Statistics } \\
\hline & & $B$ & Std. Error & & & & Tolerance & VIF \\
\hline 1 & (Constant) & 15.615 & 3.098 & & 5.040 & .000 & & \\
\hline & Budaya Organisasi (X1) & .262 & .093 & .314 & 2.815 & .007 & .827 & 1.210 \\
\hline & $\begin{array}{l}\text { Komitmen } \\
\text { Organisasional (X2) }\end{array}$ & & .056 & .446 & 3.994 & .000 & .827 & 1.210 \\
\hline
\end{tabular}

a. Dependent Variable: Kinerja $(\mathrm{Y})$

Kedua variabel independen yakni X1 dan X2 memiliki nilai VIF dalam batas toleransi yang telah ditentukan (tidak melebihi 4 atau 5), sehingga tidak menjadi multikolinearitas dalam variabel independent penelitian ini.

\section{c. Heterokedastisitas}

Heterokedastisitas digunakan untuk menguji apakah dalam model regresi, terjadi ketidaksamaan varians dari suatu pengamatan yang lain. Jika variasi residual dari suatu pengamatan ke pengamatan yang lain tetap, maka disebut homokedastisitas, dan jika varians berbeda disebut heterokedastisitas. Model yang baik adalah tidak terjadi heterokedastisitas. Dasar pengambilan keputusanya adalah : jika pola tertentu, seperti titik-titik (poin-poin) yang ada membentuk suatu pola tertentu yang teratur, maka terjadi heterokedastisitas. Jika tidak ada pola yang jelas, serta titik-titik (poin-poin) menyebar dibawah 0 pada sumbu y maka tidak terjadi heterokedastisitas. 


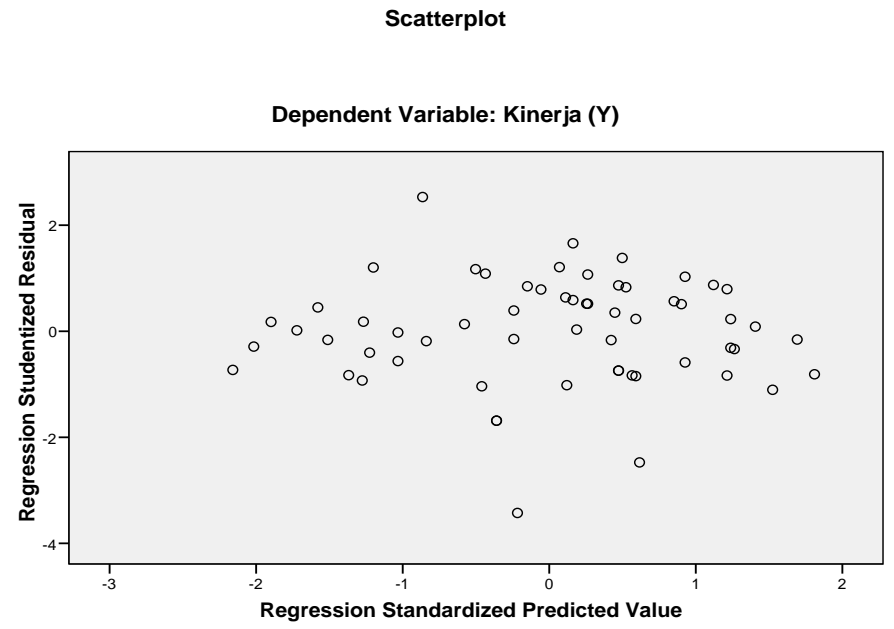

Gambar 2. Heterokedastitas

Gambar diatas memperlihatkan titik-titik menyebar secara acak, tidak membentuk pola yang jelas/teratur, serta tersebar baik diatas maupun dibawah angka 0 pada sumbu Y. dengan demikian "tidak terjadi heterokedastisitas" pada model regresi.

\section{Analisis Regresi Berganda}

Persamaan regresi berganda dapat dilihat dari nilai koefisien B pada tabel berikut ini: 
Tabel 3. Koefisien Regresi

Coefficients

\begin{tabular}{|c|c|c|c|c|c|c|}
\hline \multirow[b]{2}{*}{ Mod } & & \multicolumn{2}{|c|}{$\begin{array}{c}\text { Unstandardized } \\
\text { Coeff icients }\end{array}$} & \multirow{2}{*}{$\begin{array}{l}\text { Standardized } \\
\text { Coefficients } \\
\text { Beta }\end{array}$} & \multirow[b]{2}{*}{$t$} & \multirow[b]{2}{*}{ Sig. } \\
\hline & & $\mathrm{B}$ & Std. Error & & & \\
\hline \multirow[t]{3}{*}{1} & (Constant) & 15.615 & 3.098 & & 5.040 & .000 \\
\hline & Buday a Organisasi (X1) & .262 & .093 & .314 & 2.815 & .007 \\
\hline & $\begin{array}{l}\text { Komitmen } \\
\text { Organisasional (X2) }\end{array}$ & .223 & .056 & .446 & 3.994 & .000 \\
\hline
\end{tabular}

a. Dependent Variable: Kinerja $(\mathrm{Y})$

Sumber : Data Penelitian (Diolah)

Dari perhitungan dengan menggunakan program komputer dengan menggunakan SPSS (Statistical Program For Social Schedule) Versi 15,0 di dapat:
$\mathrm{a}=15,615$
$\mathrm{b}_{1}=0,262$
$\mathrm{b}_{2}=0,223$

Jadi persamaan regresi ganda linier untuk dua prediktor (budaya organisasi dan komitmen organisasi) adalah:

$\mathrm{Y}=15,615+0,262 \mathrm{X}_{1}+0,223 \mathrm{X}_{2}$

Persamaan di atas memperlihatkan bahwa semua variabel bebas (budaya organisasi dan komitmen organisasi) memiliki koefisien $b_{i}$ yang positif sehingga dapat diartikan jika budaya organisasi dan komitmen organisasi ditingkatkan maka akan meningkatkan kinerja karyawan, atau seluruh variabel bebas mempunyai pengaruh yang searah terhadap variabel Y (kinerja karyawan). Variabel budaya organisasi $\left(\mathrm{X}_{1}\right)$ memiliki kontribusi relatif yang paling besar di antara kedua variabel bebas terhadap kinerja karyawan.

\section{Pengujian Hipotesis}

\section{a. Pengujian Secara Parsial}

Pengujian pengaruh variabel-variabel bebas $(\mathrm{X})$ terhadap variabel terikat $(\mathrm{Y})$ dapat dilihat pada tabel berikut ini:

\section{Tabel 4. Uji t}

Coefficients

\begin{tabular}{|c|c|c|c|c|c|c|}
\hline \multirow[b]{2}{*}{ Model } & & \multicolumn{2}{|c|}{$\begin{array}{l}\text { Unstandardized } \\
\text { Coeff icients }\end{array}$} & \multirow{2}{*}{$\begin{array}{l}\text { Standardized } \\
\text { Coeff icients } \\
\text { Beta }\end{array}$} & \multirow[b]{2}{*}{$\mathrm{t}$} & \multirow[b]{2}{*}{ Sig. } \\
\hline & & B & Std. Error & & & \\
\hline 1 & (Constant) & 15.615 & 3.098 & & 5.040 & .000 \\
\hline & Buday a Organisasi (X1) & .262 & .093 & .314 & 2.815 & .007 \\
\hline & $\begin{array}{l}\text { Komitmen } \\
\text { Organisasional (X2) }\end{array}$ & .223 & .056 & .446 & 3.994 & .000 \\
\hline
\end{tabular}

a. Dependent Variable: Kinerja $(\mathrm{Y})$

1) Pengaruh Budaya organisasi Terhadap Kinerja karyawan

Dari tabel 4, diperoleh hasil signifikan t pengaruh variabel budaya organisasi $\left(\mathrm{X}_{1}\right)$ terhadap kinerja karyawan (y) 2,815 (sig 0,007), dimana signifikan t lebih kecil dari $\alpha=0,05$. Hal tersebut berarti bahwa budaya organisasi $\left(X_{1}\right)$ secara parsial mempunyai pengaruh yang signifikan terhadap kinerja karyawan $(\mathrm{Y})$.

2) Pengaruh Komitmen organisasi Terhadap Kinerja karyawan 
Dari tabel 4, diperoleh hasil signifikan t pengaruh variabel komitmen organisasi $\left(\mathrm{X}_{2}\right)$ terhadap kinerja karyawan (Y) 3,994 (sig 0,000), dimana signifikan t lebih kecil dari $\alpha=0,05$. Hal tersebut berarti bahwa komitmen organisasi $\left(\mathrm{X}_{2}\right)$ secara parsial mempunyai pengaruh yang signifikan terhadap kinerja karyawan $(\mathrm{Y})$.

\section{b. Pengujian Secara Serempak}

Data yang diperlukan untuk menguji hipotesis di atas adalah sebagai berikut:

Tabel 5. ANOVA

ANOVA

\begin{tabular}{|c|c|c|c|c|c|c|}
\hline \multicolumn{2}{|c|}{ Model } & $\begin{array}{l}\text { Sum of } \\
\text { Squares }\end{array}$ & df & Mean Square & $\mathrm{F}$ & Sig. \\
\hline \multirow[t]{3}{*}{1} & Regression & 142.960 & 2 & 71.480 & 20.102 & $.000^{a}$ \\
\hline & Residual & 202.690 & 57 & 3.556 & & \\
\hline & Total & 345.650 & 59 & & & \\
\hline
\end{tabular}

a. Predictors: (Constant), Komitmen Organisasional (X2), Budaya Organisasi (X1)

b. Dependent Variable: Kinerja $(Y)$

Sumber : Data Penelitian (Diolah)

Nilai $F$ pada tabel 5, di atas adalah 20,102 dengan sig $0,000<\alpha_{0,05}$, menunjukan Ho ditolak dan Ha diterima, berarti budaya organisasi $\left(\mathrm{X}_{1}\right)$ dan komitmen organisasi $\left(\mathrm{X}_{2}\right)$ berpengaruh secara signifikan terhadap kinerja (Y) pada taraf $\alpha_{0,05}$.

\section{PEMBAHASAN}

Dari hasil pengujian terlihat bahwa semua variabel bebas (budaya organisasi dan komitmen organisasi) mempunyai pengaruh terhadap variabel $\mathrm{Y}$ (kinerja). Lebih rinci hasil analisis dan pengujian tersebut dapat dijelaskan sebagai berikut:

\section{Pengaruh Budaya organisasi terhadap Kinerja karyawan}

Terdapat pengaruh positif variabel $\mathrm{X}_{1}$ (budaya organisasi) terhadap variabel $\mathrm{Y}$ (kinerja karyawan) yang ditunjukkan oleh hasil signifikan t sebesar 2,815 (sig 0,007), dimana signifikan t lebih kecil dari $\alpha=0,05$. Hal ini berarti bahwa budaya organisasi $\left(\mathrm{X}_{1}\right)$ secara parsial mempunyai pengaruh yang signifikan terhadap kinerja karyawan (Y).

Penelitian ini mendukung teori yang dikemukakan oleh Edy Sutrino (2010 : 6) menyatakan bahwa: Budaya organisasi yang benar-benar dikelola sebagai alat manajemen akan berpengaruh dan menjadi pendorong bagi karyawan untuk berperilaku positif, dedikatif dan produktif. Nilai-nilai budaya itu tidak tampak, tetapai merupakan kekuatan yang mendorong perilaku untuk menghasilkan efektivitas kinerja." Robert Kreitner dan Angelo Kunicki dalam Sopiah (2008 : 183) mengemukakan "Ada pengaruh budaya organisasi terhadap kinerja". Dimana jika perusahaan memiliki budaya organisasi yang baik maka berdampak pada peningkatan kinerja, demikian juga menurut Wilda dan Azra (2007), Mulyadi dkk (2012), Gultom (2014) dalam penelitiannya mengungkapkan bahwa budaya organisasi berpengaruh positif dan signifikan terhadap kinerja karyawan.

Sehingga apabila variabel ini ditingkatkan, maka kinerja pegawai akan meningkat dan apabila variabel ini dihilangkan maka kinerja pegawai akan menurun. Dapat dilihat dari nilai signifikansinya $<0,05$, yakni sebesar 0,007 maka variabel budaya organisasi berpengaruh signifikan terhadap kinerja pegawai.

\section{Pengaruh Komitmen Organisasi terhadap Kinerja karyawan}

Terdapat pengaruh positif variabel $\mathrm{X}_{1}$ (komitmen organisasi) terhadap variabel $\mathrm{Y}$ (kinerja karyawan) yang ditunjukkan oleh hasil signifikan t sebesar 3,994 (sig 0,000), 
dimana signifikan t lebih kecil dari $\alpha=0,05$. Hal ini berarti bahwa komitmen organisasi $\left(\mathrm{X}_{1}\right)$ secara parsial mempunyai pengaruh yang signifikan terhadap kinerja karyawan (Y). Penelitian ini mendukung teori yang dikemukakan oleh Fred Luthans (2006 : 250) menunjukan bahwa: "ada hubungan yang positif antara komitmen organisasi dan hasil yang diinginkan seperti kinerja yang tinggi". Dimana semakin kuatnya komitmen organisasi karyawan akan meningkatkan kinerja karyawan. Dalam dunia kerja, komitmen seseorang terhadap profesinya maupun organsiasi tempat bekerja seringkali menjadi isu yangs angat penting. Bahkan beberapa organsiasi berani memasukkan unsur komitmen sebagai salah satu persyaratan untuk memegang jabatan atau posisi yang ditawarkan dalam iklan lowongan-lowongan kerja, hal ini menunjukkan pentingnya komitmen di dalam dunia kerja. Komitmen kerja di perusahaan tidak terlepas dari bentuk hubungan antara karyawan dengan pekerjaan atau profesi di tempat karyawan tersebut bekerja demi tercapainya tujuan bisnis yang diinginkan oleh perusahaan tersebut (Rozikin, 2012 : 12). Dengan demikian dapat dikatakan bahwa komitmen organisasi berpengaruh terhadap peningkatkan kinerja karyawan PT Pegadaian (Persero) Kanwil I - Medan, artinya jika komitmen organisasional karyawan dilakukan dengan baik maka kinerja karyawan akan ikut meningkat.

\section{Pengaruh Budaya organisasi dan Komitmen organisasi terhadap Kinerja Karyawan}

Persamaan regresi ganda linier untuk dua prediktor (budaya organisasi dan komitmen organisasi) adalah: $Y=15,615+0,262 \mathrm{X}_{1}+0,223 \mathrm{X}_{2}$ Persamaan di atas memperlihatkan bahwa semua variabel bebas (budaya organisasi dan komitmen organisasi) memiliki koefisien $b_{i}$ yang positif sehingga dapat diartikan jika budaya organisasi dan komitmen organisasi ditingkatkan maka akan meningkatkan kinerja karyawan. Penelitian ini menerima hipotesis, yakni ada pengaruh budaya organisasi dan komitmen organisasi terhadap kinerja karyawan pada PT Pegadaian (Persero) Kanwil I - Medan dan pengaruh tersebut adalah signifikan pada taraf $\alpha_{0,05}$. Pengaruh yang signifikan mengandung makna bahwa hasil penelitian ini yang dikatakan positif yang merupakan gambaran umum dari seluruh anggota populasi. Dengan demikian dapat dikatakan bahwa budaya organisasi dan komitmen organisasi berpengaruh terhadap peningkatkan kinerja karyawan PT Pegadaian (Persero) Kanwil I - Medan, artinya jika budaya organisasi dan komitmen organisasi dilakukan dengan baik maka kinerja karyawan akan ikut meningkat. Setiap pekerjaan yang dilakukan perlu adanya satandar dan mampu mengukur kinerja diri sendiri atau bawahan, membandingkan kinerja dengan standar sesuai dengan ketentuan yang ada, hasil dari kegiatan harus terus dievaluasi untuk menentukan kebutuhan tindakan korektif pada kegiatan yang akan datang (Nasution, 2017:16).

\section{KESIMPULAN}

Dari hasil analisis yang telah dibahas sebelumnya, maka dapat ditarik kesimpulan sebagai berikut :

1. Secara parsial, ada pengaruh positif dan signifikan variabel $X_{1}$ (budaya organisasi) terhadap variabel Y (kinerja) karyawan PT Pegadaian (Persero) Kanwil I - Medan.

2. Secara parsial, ada pengaruh positif dan signifikan variabel $X_{2}$ (komitmen organisasi) terhadap variabel Y (kinerja) karyawan PT Pegadaian (Persero) Kanwil I - Medan.

3. Secara simultan, ada pengaruh positif dan signifikan variabel $X_{1}$ (budaya organisasi) dan variabel $\mathrm{X}_{2}$ (komitmen organisasi) terhadap variabel $\mathrm{Y}$ (kinerja) karyawan PT Pegadaian (Persero) Kanwil I - Medan. 


\section{DAFTAR PUSTAKA}

Andreas Lako. (2006). Kepemimpinan dan Kinerja Organisasi, Isu, Teori dan Solusi, Cetakan Pertama, Yogyakarta : Amara Books

Edy Sutrisno (2010), Manajemen Sumber Daya Manusia, Edisi Pertama, Cetakan Pertama, Jakarta: Prenada Media.

Gultom, D. K. (2014). Pengaruh Budaya Organisasi Perusahaan Dan Motivasi Terhadap Kinerja Karyawan Pada Pt. Perusahaan Gas Negara (Persero) Tbk Medan. Jurnal Ilmiah Manajemen \& Bisnis, 14(2), 176-184.

Hariandja Mariot Tua Efendi (2009), Manajemen Sumber Daya Manusia (Pengadaan, Pengembangan, Pengkompensasian dan Peningkatan Produktivitas Pegawai), Jakarta: Grasindo.

Hasibuan, Malayu S. P (2011). Manajemen Sumber Daya Manusia, Jakarta : PT. Bumi Aksara.

Imam Ghozali. (2005). Aplikasi Analisis Multivariate Dengan Program SPSS, Edisi Ketiga, Semarang : BP-Universitas Diponegoro.

Jufrizen, J., dan Radiman. (2010 ). Efektivitas Budaya Organisasi Pelayanan Publik (Studi Kasus Di Beberapa Rumah Sakit Pemerintah Di Kota Medan). Jurnal Riset Akuntansi \& Bisnis, 10(1), 44-67.

Khairun Rozikin, 2012, Pengaruh Komitmen Organisasi Terhadap Kinerja Pegawai pada PT. Perkebunan Nusantara IV (Persero) Medan Unit Kebun Pabatu. Skripsi, FE: Universitas Sumatera Utara.

Kreitner, Robert dan Kinicki, Angelo (2013). Perilaku Organisasi. Terjemahan Erly Suandy, Edisi Pertama, Jakarta: Salemba Empat

Luthans, Fred. (2006) Perilaku Organisasi, Edisi sepuluh, Yokyakarta : Andi

Mangkunegara, AA. Anwar Prabu, (2010). Evaluasi Kinerja SDM, Cetakan Kedua, Bandung: PT Refika Aditama.

Mathis, Robert L dan Jhon H. Jackson. (2011). Manajemen Sumber Daya Manusia. Buku II, Penerjemah : Jimmy Sadeli dan Bayu Prawira Hie, Jakarta : Salemba Empat.

Nasution, M. I. (2017). Pengaruh Stres Kerja, Kepuasan Kerja Dan Komitmen Organisasi Terhadap Turnover Intention Medical Representative. MIX: Jurnal Ilmiah Manajemen. 7(3), 407-428.

Nasution, M. I. (2017). The Influence Of Supervision And Work Discipline On Performance Of State Civil Apparatus. Proceeding 3rd Sriwijaya Economics, Accounting, and Business Conference 2017, 5-18.

Pabundu, Tika, 2008, Budaya Organisasi dan Peningkatan Kinerja Perusahaan, Jakarta: Cetakan Pertama, PT Bumi Aksara.

Panggabean, Mutiara. (2009). Manajemen Sumber Daya Manusia, cetakan Kedua, Bojongkerta: Gahalia Indonesia

Riani, Asri Laksmi. (2011). Budaya Organisasi. Graha Ilmu. Yogyakarta

Robbins, Stephen P. (2013). Perilaku Organisasi, Konsep, Kontroversi, Aplikasi, Jilid II, Alih Bahasa Hadyana Pujaatmaka dan Benyamin Molan, Jakarta: Prenhallindo.

Sopiah. (2008). Perilaku Organisasional. Edisi I, Yogyakarta : Andi Offset

Sudjana. (2012). Metoda Statistika. Bandung: Tarsito

Sugiyono. (2012). Metode Penelitian Bisinis. Bandung, Cetakan Keempat, Alfabeta.

Wirawan. (2010). Evaluasi Kinerja Sumber Daya Manusia. Jakarta: Salemba Empat. 